\title{
CARGO FLOWS MANAGEMENT MODEL OF NETWORK AIR CARRIER
}

\author{
WAng Bo ${ }^{1}$, Mariya GrygoraK ${ }^{2}$, Viktor VoitsehovskiY ${ }^{2}$, \\ Sergiy Lytvynenko ${ }^{2}$, Tatiana Gabrielova ${ }^{3}$, Dmytro Bugayko ${ }^{2}$, \\ YATCHKO IVANOV $^{4^{*}}$ and ANDRIJA VIDOVIC ${ }^{5}$ \\ ${ }^{1}$ China-Central and Eastern Europe International Science \\ and Technology Achievement Transfer Center, \\ Ningbo University of Technology, \\ 201 Fenghua Rd, Jiangbei Qu, Ningbo Shi, \\ Zhejiang Sheng 315000, China, \\ e-mail: bo305@hotmail.com \\ ${ }^{2}$ Faculty of Economics and Business Administration, \\ National Aviation University, \\ 1, Kosmonavta Komarova Ave., Kyiv 03058, Ukraine, \\ e-mails: m_grigorak@ukr.net; v.voitsehovskiy@gmail.com; \\ e-mail: sllitvinenko1982@gmail.com; bugaiko@nau.edu.ua

$$
{ }^{3} L L C \text { "5PL" }
$$ \\ 2a, Kostiantynivska St., Kyiv 04071, Ukraine, \\ e-mail: t_gabrielova@ukr.net \\ ${ }^{4}$ Institute of Mechanics, \\ Bulgarian Academy of Sciences, \\ Acad. G. Bonchev St., Bl. 4, 1113 Sofia, Bulgaria, \\ e-mail: yadir_1@abv.bg \\ ${ }^{5}$ University of Zagreb, \\ Faculty of Transport and Traffic Sciences, \\ 4, Vukeliceva, 10000 Zagreb, Croatia
}

\begin{abstract}
This paper describes modeling of cargo flows management of a network air carrier by a model that allows using the advantage of well-developed packages that implement linear programming methods. Several characteristics of the underlying mathematical models are presented and the stages of the modeling process are determined.

Keywords: model of cargo traffic management, network air carrier.
\end{abstract}

\footnotetext{
${ }^{*}$ Corresponding author.

DOI: 10.7546/EngSci.LVI.19.03.01
}

(c) Инженерни науки, год. LVI, 2019, № 35

(C) Engineering Sciences, LVI, 2019, No. 3 


\section{INTRODUCTION}

The issues of simulating the networks are extensively studied in the last years [1-3]. Especially interesting is the research on flows of networks connected to airports and airlines. Several examples of such research are: planning the network of air transportation, service routing and planning of the crew schedule [4]; sequential modeling of airline networks [5]; modeling cargo flows $[6,7]$; determining airport hubs [8]; infeasibility of accounting for economies of scale in the modeling of airline networks [9]; effect of the implementation of "SolidWorks" systems of three-dimensional parametric modeling in the organization of delivering super heavy and oversized cargoes[10]. Below we consider the problem of cargo flows management of a network air carrier on the basis of logistics and discuss a two-stage model of cargo flows management. This model includes a mathematical model of rapid response in the short-term time interval, as well as a non-linear multi-product transport flow model that allows quickly taking into account information uncertainties and the risks of decreasing demand for the air carrier services.

\section{MODELS AND RESULTS}

The models of cargo transport flows are described in detail in [11, 12] (especially the mathematical part of the model is discussed in [12]). The model of carriage flows describes the selection of cargoes and the dynamics of their carriage at fixed prices for of transport and fixed demand. The non-linear dynamic model of carriage flows planning [12] describes the process of planning the sales of carriage volumes, taking into account the possibility of variation in the prices of transportation and the impact of prices on demand. In the non-linear dynamic model of carriage flows planning many variants of cargo carriage contracts are considered. Within the framework of the contract variant, both the category of cargo and the price of carriage are taken into account, as well as the initial and final period of carriage, the time interval between the conclusion of the transaction and the carriage commencement. We note that the above models have many variables and limitations and from a practical point of view, solving a problem with such a large number of limitations and variables may be problematic. Therefore we propose to reformulate the problem of cargo flows management as a two-stage one, which has made it possible to take advantage of well-developed packages, which implement linear programming methods.

(c) Инженерни науки, год. LVI, 2019, № 36

(c) Engineering Sciences, LVI, 2019, No. 3 
The stage-by-stage approach to modeling in the process of implementing the system of cargo flows management of a network air carrier based on logistics is presented in Fig. 1.

The planning of airline operations may be conditionally divided into three stages according to the time period being covered. This is prediction, ongoing and operational planning. These variants are compatible with all three proposed models. The models from Fig. 1 are linked between each other by the use of the same input information about the environment in which the airline operates, about the airline itself and information exchange, as for one model it is the input information while for the other it is the output information. The models are distinguished by the detailed nature of the information used and by the detailed description of the transport process.

The cargo flows are analyzed in the proposed model as per carriage destinations and categories in dynamics. On the grounds of information about individual cargoes, options for carriage of individual cargoes are formed. These data and information on conditions for the sale of individual cargoes carriage comprise the initial data for modeling the selection, storage and carriage of a variety of individual cargoes. Thus achieving full occupancy of the flights on the grounds of which the dynamics of carriage of the selected set of individual cargoes is established. We note that to model the planning of free tonnage, it is necessary to provide detailed statistical information on the concluded contracts and the carriage orders sold by the airline itself and by other carriers, marketing information about carriage demand and the impact of prices on demand, as well as information about the flights planned by the airline itself. Subsequently, the carriage prices are determined subject to the contract variants and destinations, as well as the planned volumes of carriage subject to the contract variants and destinations. Based on this data and information about the conditions of cargo storage at airports, the modeling of transporting cargo flows traffic and achieving full occupancy of the flights is carried out. The characteristics of the above models are shown in Table 1.

The model [12] determines the optimal price under certain conditions, the periods of such conditions, and yet not in all cases these are all the possible conditions that should be taken into account, and therefore, other additional conditions may be added. It is determined by the function what the demand under these conditions will be, depending on the price. As a result, when these queries are combined between each other, the model compares and sets the optimal prices of the carrier. In model [12] there are two important variables: how much cargo the air carrier transports and at what price. Also there is one more function, namely time indexes, and hence for different indexes there will

(c) Инженерни науки, год. LVI, 2019, № $3 \quad 7 \quad$ (c) Engineering Sciences, LVI, 2019, No. 3 


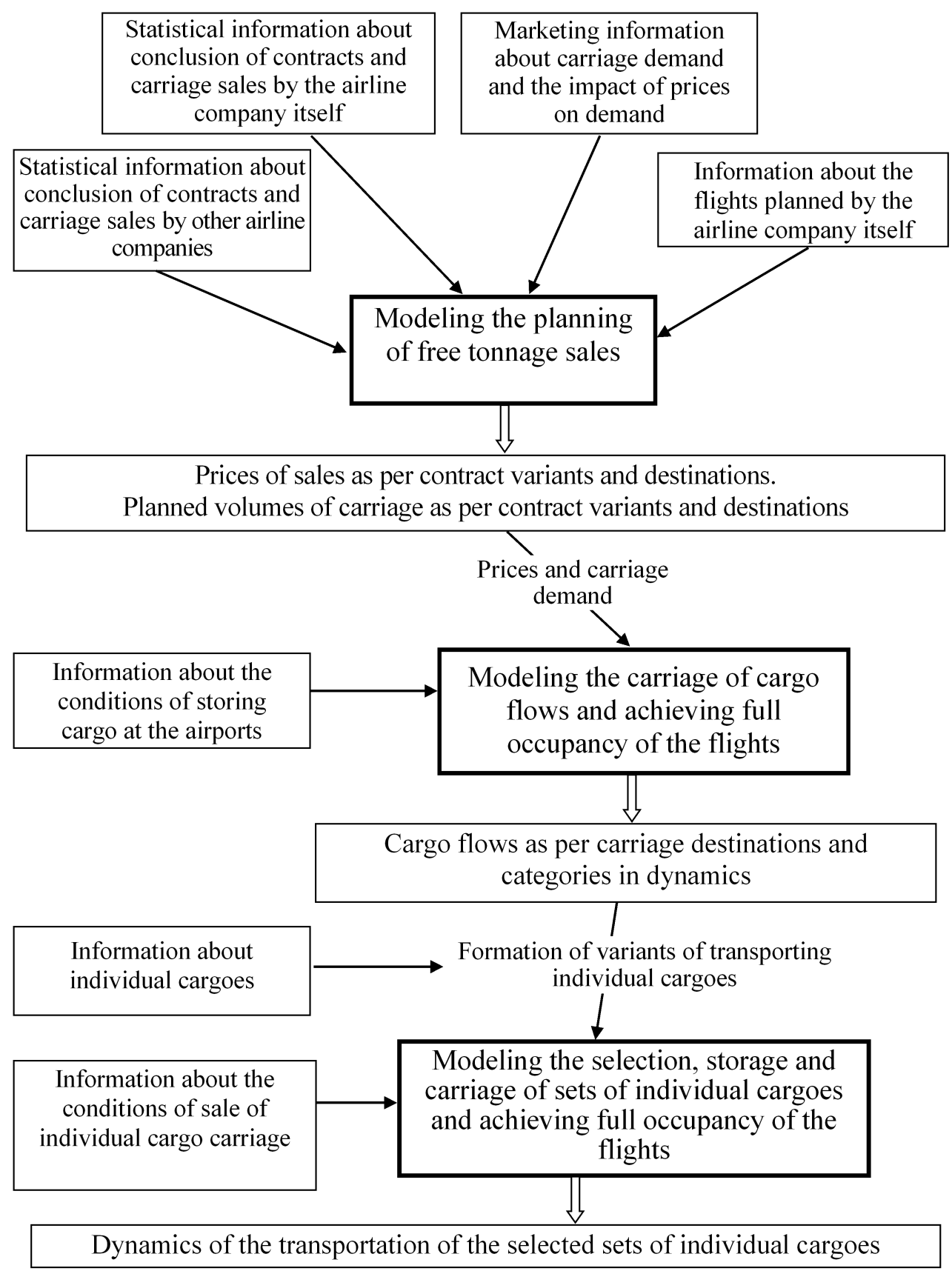

Fig. 1. Stage-by-stage approach of modeling within the process of implementation of cargo flows management of a network air carrier based on logistics

$\begin{array}{lll}\text { (c) Инженерни науки, год. LVI, 2019, № } 3 & 8 & \text { (c) Engineering Sciences, LVI, 2019, No. } 3\end{array}$ 
TABLE 1. General characteristics of the elaborated mathematical models

\begin{tabular}{|c|c|c|c|}
\hline Characteristic & $\begin{array}{l}\text { Linear dynamical } \\
\text { model of transport } \\
\text { flows }\end{array}$ & $\begin{array}{l}\text { Model of opera- } \\
\text { tional management } \\
\text { of cargo flows in } \\
\text { real-time mode }\end{array}$ & $\begin{array}{l}\text { Non-linear dynami- } \\
\text { cal model of trans- } \\
\text { port flow planning }\end{array}$ \\
\hline Designation & Carriage planning & $\begin{array}{l}\text { Carriage opera- } \\
\text { tional management }\end{array}$ & $\begin{array}{l}\text { Planning of free } \\
\text { tonnage sales }\end{array}$ \\
\hline Model type & Linear dynamical & Linear dynamical & $\begin{array}{l}\text { Non-linear dynami- } \\
\text { cal }\end{array}$ \\
\hline Variable & Continuous & $\begin{array}{l}\text { Continuous and } \\
\text { Boolean }\end{array}$ & Uninterrupted \\
\hline $\begin{array}{l}\text { Admissible } \\
\text { dimensions }\end{array}$ & May be large & $\begin{array}{l}\text { Limited by the pos- } \\
\text { sibilities for solu- } \\
\text { tions to problems } \\
\text { with Boolean vari- } \\
\text { ables }\end{array}$ & $\begin{array}{l}\text { Limited by the pos- } \\
\text { sibilities for solu- } \\
\text { tions to the non- } \\
\text { linear (nonconvex) } \\
\text { problems }\end{array}$ \\
\hline $\begin{array}{l}\text { Carriage de- } \\
\text { mand }\end{array}$ & $\begin{array}{l}\text { Fixed, aggregate } \\
\text { within the limits of } \\
\text { the categories and } \\
\text { destinations }\end{array}$ & $\begin{array}{l}\text { Fixed, individual, } \\
\text { per cargoes }\end{array}$ & $\begin{array}{l}\text { Aggregate as per } \\
\text { variants of con- } \\
\text { tracts, manifesting } \\
\text { as a function of the } \\
\text { price }\end{array}$ \\
\hline $\begin{array}{l}\text { Prices per } \\
\text { carriage }\end{array}$ & Fixed & Fixed & $\begin{array}{l}\text { Manifesting as vari- } \\
\text { ables of the model }\end{array}$ \\
\hline Cargo & $\begin{array}{l}\text { Considered as part } \\
\text { of the flow along } \\
\text { the network for } \\
\text { cargo categories }\end{array}$ & $\begin{array}{l}\text { Available indi- } \\
\text { vidual path and } \\
\text { transport means }\end{array}$ & $\begin{array}{l}\text { Considered as part } \\
\text { of the flow along } \\
\text { the network for } \\
\text { contract variants }\end{array}$ \\
\hline Storage & $\begin{array}{l}\text { In aggregate for the } \\
\text { airport }\end{array}$ & $\begin{array}{l}\text { In aggregate and in } \\
\text { aggregate per cate- } \\
\text { gories }\end{array}$ & $\begin{array}{l}\text { Not to be consid- } \\
\text { ered }\end{array}$ \\
\hline $\begin{array}{l}\text { Carriage } \\
\text { order with- } \\
\text { drawal }\end{array}$ & $\begin{array}{l}\text { Not to be consid- } \\
\text { ered }\end{array}$ & $\begin{array}{l}\text { Admissible, with } \\
\text { fines }\end{array}$ & $\begin{array}{l}\text { Not to be consid- } \\
\text { ered }\end{array}$ \\
\hline $\begin{array}{l}\text { Cargo lim- } \\
\text { itations for } \\
\text { flights }\end{array}$ & $\begin{array}{l}\text { Per categories and } \\
\text { in general }\end{array}$ & $\begin{array}{l}\text { Per categories and } \\
\text { in general }\end{array}$ & In general \\
\hline
\end{tabular}

(c) Инженерни науки, год. LVI, 2019, № 399 (c) Engineering Sciences, LVI, 2019, No. 3 
be different functions that depend on the price in a certain way. The condition that the greater the price the more we earn will also be valid here, and yet the demand for the capacity offered by the air carrier will then diminish. Table 2 shows a fragment of initial data of the cargo flow management model according to the data of the "Ukraine International Airlines" for 2016 [13].

The necessity of use of a two-stage model of cargo flows management comes from the fact that the use of a non-linear model is difficult to optimize, and because of this we propose to divide this optimization into two stages:

1. In one of the stages to change a part of the variables;

2. In the other stage to change the variables.

For instance, if prices are fixed in the model, then a linear model is obtained at a fixed price. Then if it is linear, a double variable must be calculated, as these double variables indicate what the best change in the price is in order to improve the solution of the problem derived at a fixed price. Prices are further adjusted, the solution of the problem is modeled again, and then we again individualize these double variables, as by analyzing same, we can see that with a slight price adjustment in a certain direction we are able to obtain an even more optimal solution. Therefore, it is necessary to solve the problem in two stages - firstly considering that the prices are fixed, and then after having received information about the optimal solution, and having accordingly adjusted the prices, we make an iteration as per new prices, and solve the problem again. All this is being solved in such cycle, until stabilized, thus resulting in a two-stage problem.

\section{CONCLUDING REMARKS}

When managing the cargo flows by using the proposed two-stage model, the air carrier will be able to manage revenues and expenses when performing passenger-cargo flights in real time. Since the costs of loading cargo on a passenger flight are very difficult to measure accurately, and since it is practically impossible to separate the cost of transporting cargo load from passenger load, it is necessary to use assumptions.

In general, it was found that upon transporting additional cargo loads the expenses will change insignificantly, the fuel costs will increase slightly due to the increase in commercial load. Revenues from loading cargo are measured more accurately while taking into account the known freight tariffs and the size of the load of flights. An increase in the cargo load of a passenger flight will allow for a significant net profit of the network air carrier, as the costs

(c) Инженерни науки, год. LVI, 2019, № 310 (c) Engineering Sciences, LVI, 2019, No. 3 
TABLE 2. Fragment of initial data of the cargo flow management model

\begin{tabular}{|c|c|c|c|c|c|c|c|}
\hline Route & $\begin{array}{c}\text { Number of } \\
\text { packages }\end{array}$ & $\begin{array}{c}\text { Actual } \\
\text { weight, kg }\end{array}$ & $\begin{array}{c}\text { Departure } \\
\text { date }\end{array}$ & $\begin{array}{l}\text { Paid weight, } \\
\text { kg }\end{array}$ & $\begin{array}{l}\text { Tariff, } \\
\text { USD }\end{array}$ & $\begin{array}{c}\text { Other charges, } \\
\text { USD }\end{array}$ & $\begin{array}{c}\text { Revenue, } \\
\text { USD }\end{array}$ \\
\hline JFK-KBP & 1 & 1 & $02 \operatorname{Jan} 16$ & 1 & SERVICE & & 0 \\
\hline JFK-KBP & 1 & 3 & 02 Jan 16 & 3 & SERVICE & & 0 \\
\hline JFK-KBP & 1 & 1 & 02 Jan 16 & 1 & SERVICE & & 0 \\
\hline JFK-KBP & 1 & 1 & $02 \operatorname{Jan} 16$ & 1 & SERVICE & & 0 \\
\hline KBP-PEK & 32 & 13805 & 03 Jan 16 & 13805 & 0.90 & & 12425 \\
\hline KBP-PEK & 12 & 459 & 03 Jan 16 & 500 & 1.00 & & 500 \\
\hline JFK-KBP & 6 & 1940 & 03 Jan 16 & 1940 & 1.15 & 0.7 & 3589 \\
\hline JFK-KBP & 2 & 250 & 03 Jan 16 & 377.6 & 1.35 & 0.7 & 685 \\
\hline PEK-KBP & 1 & 136 & $04 \operatorname{Jan} 16$ & 136 & 4.45 & 0.2 & 632 \\
\hline PEK-KBP & 65 & 1170 & 04 Jan 16 & 1327 & 3.50 & 0.2 & 4879 \\
\hline KBP-PEK & 21 & 199 & 05 Jan 16 & 200 & 1.75 & & 350 \\
\hline KBP-JFK & 18 & 445 & 06 Jan 16 & 500 & 1.40 & & 700 \\
\hline KBP-PEK & 23 & 543 & 06 Jan 16 & 543 & 1.00 & & 543 \\
\hline PEK-KBP & 107 & 2505 & $06 \operatorname{Jan} 16$ & 2505 & 3.50 & 0.2 & 9269 \\
\hline KBP-JFK & 1 & 10.2 & 07 Jan 16 & 10.2 & SERVICE & & 0 \\
\hline KBP-TBS & 2 & 67 & 07 Jan 16 & 67 & 1.50 & 5 & 106 \\
\hline JFK-KBP & 1 & 167.8 & 07 Jan 16 & 179 & 1.35 & 0.7 & 359 \\
\hline JFK-KBP & 4 & 895 & $07 \operatorname{Jan} 16$ & 1728 & 1.15 & 0.7 & 2614 \\
\hline JFK-HEL & 1 & 49 & 07 Jan 16 & 49 & 2.20 & 0.7 & 142 \\
\hline JFK-KBP & 1 & 1 & 07 Jan 16 & 2 & SERVICE & 0.7 & 0 \\
\hline JFK-KBP & 27 & 2200.9 & 07 Jan 16 & 2201 & 1.15 & 0.7 & 4072 \\
\hline
\end{tabular}


will increase at insignificant rate, and the revenues from cargo transportation will increase significantly.

\section{REFERENCES}

[1] L. D. Ford JR. And D. R. Fulkerson, Flows in Networks, Princeton University Press, Princeton, NJ (2010) 216.

[2] N. K. Vitanov and K. N. Vitanov, Math. Soc. Sciences (2016) 80 108-114.

[3] N. K. Vitanov and K. N. Vitanov, Physica A (2018) 509 635-650.

[4] C. Schön, Optimal Service Design, Habilitation at the School of Economics and Business Engineering, University of Karlsruhe (2008).

[5] C. Barnhart And A. Cohn, Manufacturing and Service Operations Management (2004) 6 (1) 3-22.

[6] U. Derigs, St. Friederichs And S. SchäFer, Transportation Science (2009) 43 (3) 370-380.

[7] C. SCHÖN, Market-oriented airline service design, in: Operations Research Proceedings (Eds K.-H. Waldmann, U. M. Stocker), Springer, Berlin Heidelberg (2007) 362-366.

[8] S. Alumur and B.Y. Kara, Network hub location problem: The state of the art, European Journal of Operations Research (2008) 190 1-21.

[9] A. Kimms, Economies of scale in hub $\&$ spoke network design models: We have it all wrong, in: Perspectives on Operations Research - Essays in honour of K. Neumann (Eds M. Morlock et al.). Gabler Publishing, Wiesbaden (2006) 293317.

[10] S. Lytvynenko, Forecast economic effect of using information systems "SolidWorks" by cargo air carriers of Ukraine, Actual Problems of Economics (2012) 1 170-175 (in Ukrainian).

[11] V. Voitsehovskiy, European Cooperation (2016) 11 34-41.

[12] V. VoitsenovskiY, Scientific Journal "Transactions of Kremenchuk Mykhailo Ostrohradskyi National University" (2017) 4 (105) 50-55 (in Ukrainian).

[13] "Ukraine International Airlines" PJSC. Annual financial statements of the emitter, 2016 Available at: https://smida.gov.ua/db/emitent/year/xml/showform $/ 98863 / 165 /$ templ.

(c) Инженерни науки, год. LVI, 2019, № 3 


\title{
МОДЕЛ ЗА УПРАВЛЕНИЕ НА ТОВАРНИ ПОТОЦИ НА МРЕЖОВ ВЪЗДУШЕН ПРЕВОЗВАЧ
}

\author{
Wang Bo ${ }^{1}$, Mariya Grygorak ${ }^{2}$, Viktor Voitsehovskiy ${ }^{2}$, \\ Sergiy LytVynenko ${ }^{2}$, Tatiana Gabrielova ${ }^{3}$, Dmytro Bugayko ${ }^{2}$, \\ Ячко Иванов ${ }^{4 *}$ AND ANDRIJA Vidovic ${ }^{5}$ \\ ${ }^{1}$ China-Central and Eastern Europe International Science \\ and Technology Achievement Transfer Center, \\ Ningbo University of Technology, \\ 201 Fenghua Rd, Jiangbei Qu, Ningbo Shi, \\ Zhejiang Sheng 315000, China, \\ e-mail:bo305@hotmail.com \\ ${ }^{2}$ Faculty of Economics and Business Administration, \\ National Aviation University, \\ 1, Kosmonavta Komarova Ave., Kyiv 03058, Ukraine, \\ e-mails:m_grigorak@ukr.net; v.voitsehovskiy@gmail.com; \\ e-mail: sllitvinenko1982@gmail.com; bugaiko@nau.edu.ua

$$
{ }^{3} L L C \text { " } 5 P L "
$$ \\ 2a, Kostiantynivska St., Kyiv 04071, Ukraine, \\ e-mail: t_gabrielova@ukr.net \\ ${ }^{4}$ Институт по механика, \\ Българска академия на науките, \\ ул. Акад. Г. Бончев, Бл. 4, 1113 София, Бглгария, \\ e-mail: yadir_1@abv.bg \\ ${ }^{5}$ University of Zagreb, \\ Faculty of Transport and Traffic Sciences, \\ 4, Vukeliceva, 10000 Zagreb, Croatia
}

Резюме. Статията описва моделирането на управлението на товарни потоци на мрежов въздушен превозвач чрез модел, който позволява да се използва предимството на добре развити линейни методи за проектиране. Представени са няколко характеристики на базовите математически модели и са определени етапите на моделирането.

Ключови думи: модел за управление на товарни потоци, мрежов въздушен превозвач.

Received September 09, 2019

(c) Инженерни науки, год. LVI, 2019, № 3 